\title{
Experimental Nearly Zero Energy Building with Green Technology - Renovation Pilot through Passive House Expertise
}

\author{
Horia Petran ${ }^{1, *}$, Szabolcs Varga ${ }^{2}$ and Noémi Fogas ${ }^{2}$ \\ ${ }^{1}$ National Institute for Research \& Development URBAN-INCERC, Sos. Pantelimon 266, 021652 Bucharest, Romania \\ ${ }^{2}$ V\&V Projekt srl, str. Gödri Ferenc, nr. 2/31, 520023 Sfântu Gheorghe, jud. Covasna, România
}

\begin{abstract}
The paper presents the preliminary planning of a demonstration pilot for exemplary renovation of an existing building ("Solar House 1 - Campina") towards nZEB level using Passive House principles and technologies. The "Solar House" was one of the lighthouses of solar energy developments in the "80s in Romania, being built in 1977-1978 in Campina (Centre-South Romania) and represented an experimental building using innovative solar technologies for DHW preparation, active and passive space heating. The decision of transforming the existing building in a demonstration pilot nZEB with green materials was taken and the feasibility study is currently underway. The pilot aims to analyse and test, the cost effectiveness of Passive House $(\mathrm{PH})$ technologies integration in a deep renovation process with the view to achieve the fixed nZEB levels, as an exemplary case study demonstrating the benefits and feasibility of applying $\mathrm{PH}$ principles and energy performance evaluation in real context. Both approaches of applying the renovation standard EnerPHit and targeting Passive House criteria are discussed together with the nZEB targets, while the analysis of technical (energy performance) and economic (total costs) feasibility is presented. The proposed building will act as a training and consultancy centre in Campina - created as a model for achieving greater energy efficiency and environmental responsibility in Romania.
\end{abstract}

\section{INTRODUCTION}

The Nearly Zero Energy Building (nZEB) concept [1-2] does not seem to be easily applicable yet in Romania. Gaining the confidence of building industry and building owners in the real nZEB energy performance, supported by the understanding and application of Passive House principles appear to be strategic issues. Their solution could facilitate the up-taking of investments required in the process of increasing energy efficiency of existing building stock. In this context, the paper presents the preliminary analysis performed with the view to develop a demonstration pilot for exemplary renovation of an existing building ("Solar House 1 - Campina") towards nZEB level using Passive House principles and technologies.

The "Solar House" (Figure 1) was one of the lighthouses of solar energy developments in the " $80 \mathrm{~s}$ in Romania, being built in 1977-1978 in Câmpina (CentreSouth Romania) and represented an experimental building using innovative solar technologies for DHW preparation, active and passive space heating.

The construction, experimentally designed as a duplex house, using solar energy heaters, was provided with a south-facing capillary wall at an angle of $65^{\circ}$ with the horizontal plane. The wall, composed of flat heliothermic shutter panels, was mounted on a metal structure.

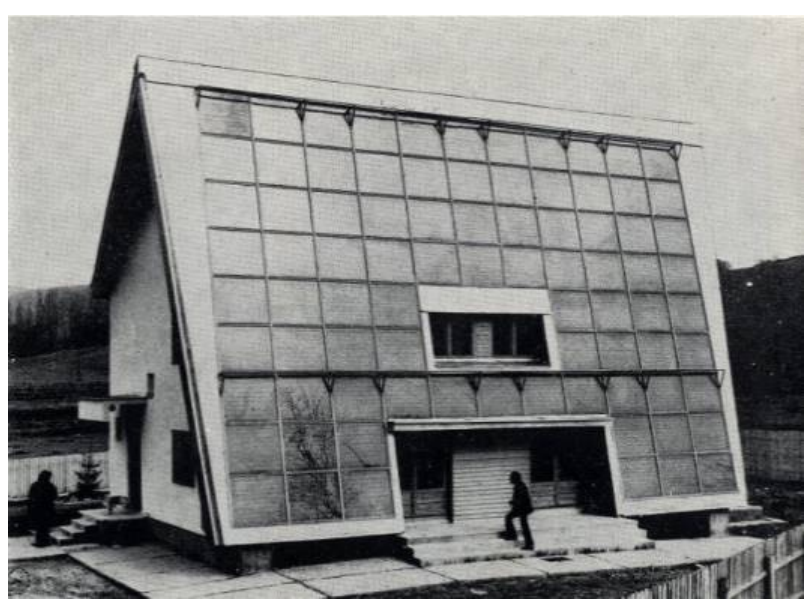

Fig. 1. The Solar House Câmpina, Romania (1980)

In the last 15 years the building has not been occupied and it is currently in an advanced degradation state, needing major renovation (Figure 2). The decision of transforming the existing building in a demonstration pilot nZEB with green materials was taken and the feasibility study is currently under development. The analysis presented in this paper represents a consistent contribution to the selection of the final package of measures included in the final renovation solution in the feasibility study.

\footnotetext{
* Corresponding author: $\underline{\text { hp@,incerc2004.ro }}$
} 


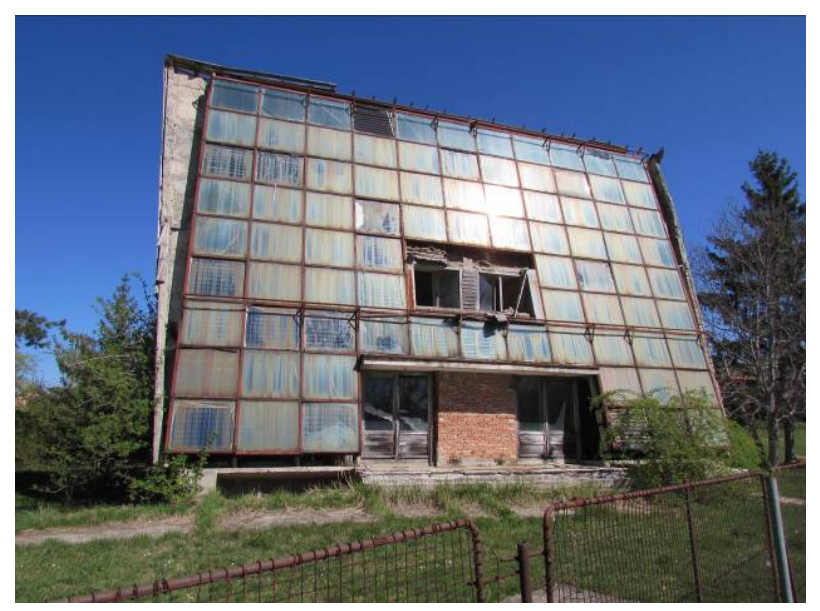

Fig. 2. The Solar House Câmpina, Romania (2017)

The pilot aims to analyse and test, the cost effectiveness of Passive House (PH) technologies integration in a deep renovation process with the view to achieve the fixed nZEB levels, as an exemplary case study demonstrating the benefits and feasibility of applying $\mathrm{PH}$ principles and energy performance evaluation in real context. Both approaches of applying the renovation standard EnerPHit and targeting Passive House criteria is discussed together with the nZEB targets, while the analysis of technical (energy performance) and economic (total costs) feasibility is briefly presented.

The proposed building is intended to be used as a training and consultancy centre in the region - created as a model for achieving greater energy efficiency and environmental responsibility in Romania.

\section{MATERIALS AND METHODS}

\subsection{Initial stage and starting point}

The building was designed and built with special features and original (INCERC) technology in order to use available solar energy as much as possible and to reduce the fuel consumption:

- Solar radiation collectors: modulated plane solar flat panels, INCERC type, with metal housing,

aluminium plate caps and transparent two-row glass screen;

- Thermal energy storage: thermal insulated tank containing $10 \mathrm{~m}^{3}$ of water;

- Thermal agent: water mixture with ethylene glycol;

- Supply of thermal energy: the eastern apartment was equipped with fan coils, and the western apartment with radiant panels;

- Electrical complementary heating;

- Participation of the solar installation: heating and domestic hot water preparation;

- Thermal insulation: the global coefficient of thermal loss $\mathrm{G}=0.67 \mathrm{~W} / \mathrm{m}^{3} \mathrm{~K}$.

The building comprises two residential units developed in two stories, with unheated basement and attic.
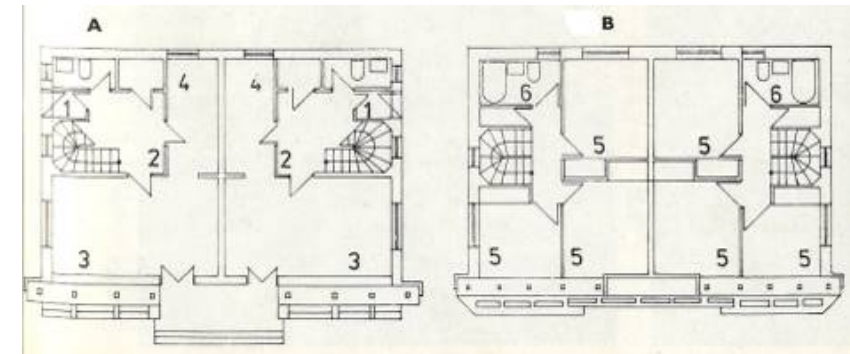

Fig. 3. Initial design (INCERC archives)

(A - Ground Floor, B - 1 $^{\text {st }}$ level; 1-vestibule, 2-hall/stairs, 3living room, 4- kitchen, 5-bedroom, 6-bathroom)

During the experimental research period, on the basis of measured data, the building approached the theoretically estimated performance, respectively a 50\% reduction in fuel consumption meaning an annual economy of $12.5 \mathrm{MWh}$.

The symbolic importance of the Campina Solar House and the current state of the building demanding major renovation, lead to the performance of a feasibility study of solutions to be applied in order reach nZEB levels through implementing the Passive House renovation approach.

\subsection{Energy \& cost model}

\subsection{1 nZEB and Passive House standards}

The nZEB standard defined for Romania is intended to be applied as mandatory requirement only for new built, being compulsory for public buildings since 2019 and for all buildings after the end of 2020 [2]. For the deep renovation of existing buildings minimum requirements apply since 2017 [3], but although tighter than previous performance indicators, they are far from the fixed nZEB levels.

In order to achieve the nZEB standard, a building must fulfil the requirements established for three performance indicators based on the use of the building and the climatic zone for the specific location: the maximum admissible level of primary energy from fossil sources (1) and of $\mathrm{CO} 2$ emissions for the use of the building (2) and the minimum share of renewable nonfossil sources of the total calculated primary energy of the building.

For Câmpina, the following requirements are set for residential and office buildings [4]:

Table 1. Relevant nZEB requirements (new built, Romania).

\begin{tabular}{|c|c|c|c|}
\hline $\begin{array}{c}\text { Performance } \\
\text { indicator }\end{array}$ & Unit & $\begin{array}{c}\text { Threshold for } \\
\text { individual } \\
\text { residential } \\
\text { buildings }\end{array}$ & $\begin{array}{c}\text { Threshold } \\
\text { for office } \\
\text { buildings }\end{array}$ \\
\hline $\begin{array}{c}\text { Primary } \\
\text { energy (PE) }\end{array}$ & $\mathrm{kWh} / \mathrm{m}^{2} \mathrm{a}$ & 111 & 57 \\
\hline $\begin{array}{c}\mathrm{CO} 2 \\
\text { emissions }\end{array}$ & $\mathrm{kg} / \mathrm{m}^{2} \mathrm{a}$ & 30 & 15 \\
\hline $\begin{array}{c}\text { RES share } \\
\text { (RER) }\end{array}$ & $\%$ & 10 & 10 \\
\hline
\end{tabular}


Currently there are no partial performance indicators to help the definition of an nZEB building, although the methodology [3] is under revision and it is expected to provide some recommendations in this respect in the near future. In this context the application of the Passive House concept and Passive House technologies seems to be a valuable basis for the implementation of sustainable building concepts in order to achieve the nZEB level of performance, both for new built and for deep energy retrofit.

Passive House is a building, for which thermal comfort (ISO 7730) can be achieved solely by postheating or post-cooling of the fresh air mass, which is required to achieve sufficient indoor air quality conditions - without the need for additional recirculation of air [5]. The Passive House standard is defined by a number of criteria together with measurable performance indicators and evaluation tools [6]. For Passive House Classic, these criteria are:

- Maximum heating/cooling load $10 \mathrm{~W} / \mathrm{m}^{2}$ or maximum space heating/cooling energy demand $15 \mathrm{kWh} /\left(\mathrm{m}^{2} \mathrm{a}\right)$,

- Maximum conventional primary energy use of $120 \mathrm{kWh} /\left(\mathrm{m}^{2} \mathrm{a}\right)$ - including appliances,

- Air tightness limited to $\mathrm{n}_{50}=0.6 / \mathrm{h}$ air change rates at a pressure differential of $50 \mathrm{~Pa}$,

- Maximum overheating in summer (excessive temperatures may not occur more than $10 \%$ of the time).

The Passive House Standard often cannot be feasibly achieved in existing buildings due to various difficulties. Thus, for refurbishment the EnerPHit Standard has been defined. This can be achieved through compliance with the criteria of the energy demand method (Table 2). or alternatively through compliance with the criteria of the component method (Table 3 ), having to meet only the criteria of one of these methods.

Table 2. EnerPHit criteria for the building component method (Cool-temperate climate zone)

\begin{tabular}{|l|c|c|c|}
\hline \multicolumn{1}{|c|}{ Criteria } & Unit & Value \\
\hline \multicolumn{2}{|c|}{ U-value for external insulation } & $\mathrm{W} / \mathrm{m}^{2} \mathrm{~K}$ & $<0.15$ \\
\hline \multicolumn{2}{|l|}{ U-value for internal insulation } & $\mathrm{W} / \mathrm{m}^{2} \mathrm{~K}$ & $<0.35$ \\
\hline \multirow{2}{*}{$\begin{array}{l}\text { U-value windows } \\
\text { (installed) }\end{array}$} & $\mathrm{W} / \mathrm{m}^{2} \mathrm{~K}$ & $<0.85$ \\
\cline { 2 - 4 } & $\mathrm{W} / \mathrm{m}^{2} \mathrm{~K}$ & $<1.00$ \\
\hline $\begin{array}{l}\text { Solar heat gain coefficient - } \\
\text { glazing (Ug - g*1.6) }\end{array}$ & $\mathrm{W} / \mathrm{m}^{2} \mathrm{~K}$ & $<1.10$ \\
\hline Specific solar load cooling period & $\mathrm{kWh} / \mathrm{m}^{2} \mathrm{~K}$ & $\leq 0$ \\
\hline Min. heat recovery rate & $\%$ & $<100$ \\
\hline
\end{tabular}

Table 3. EnerPHit criteria for the energy demand method (Cool-temperate climate zone)

\begin{tabular}{|l|c|c|}
\hline \multicolumn{1}{|c|}{ Criteria } & Unit & Value \\
\hline Space heating demand & $\mathrm{kWh} / \mathrm{m}^{2} \mathrm{a}$ & $<25$ \\
\hline Space cooling+dehumid. demand & $\mathrm{kWh} / \mathrm{m}^{2} \mathrm{a}$ & PH req. \\
\hline
\end{tabular}

In addition to these criteria, the measured air leakage must not exceed $1 \mathrm{~h}^{-1}$ at a pressure differential of $50 \mathrm{~Pa}$, while domestic hot water generation and distribution systems with minimal heat losses must be used. While for nZEB the total energy use does not taking into account the consumption of appliances, highly efficient use of household electricity is essential for a Passive House.

The EnerPHit categories Classic, Plus or Premium may be achieved depending on the renewable primary energy (PER) demand and generation of renewable energy.

\subsubsection{Energy balance model}

For the energy modelling of the building The Passive House Planning Package (PHPP 2015, version 9.6) was used [6]. The possibility of planning and assessing efficient projects in a reliable way makes the PHPP a very good planning tool for the implementation of NZEBs (Nearly Zero-Energy Buildings), which has been proven successful over many years.

The PHPP enables the calculation of the energy demand; renewable energy sources can also be incorporated into the planning process and the overall efficiency of a building in the future can also be assessed.

For the calculations, the climatic data should be derived from long term average parameters and hourly data characteristic of the climatic year type. Since no reliable climatic data are available in order to produce the input data for Câmpina in the PHPP format, data from different locations were processed based on available data, as follows:

- Monthly average temperatures and humidity were calculated as distance-weighted values from 5 cities located at the shortest distance from Câmpina around (Bucharest, Buzau, Ploiesti, Brasov and Targoviste),

- Solar radiation values were considered from Bucharest average values,

- Data for defining the heating and cooling load conditions were calculated as average values of data calculated for Bucharest and Brasov from the Test Reference Year.

Thus, it resulted a virtual climatic data set ready to be used in PHPP. Figure 3 shows the outdoor temperature and solar radiation values. all directions, as monthly averages.

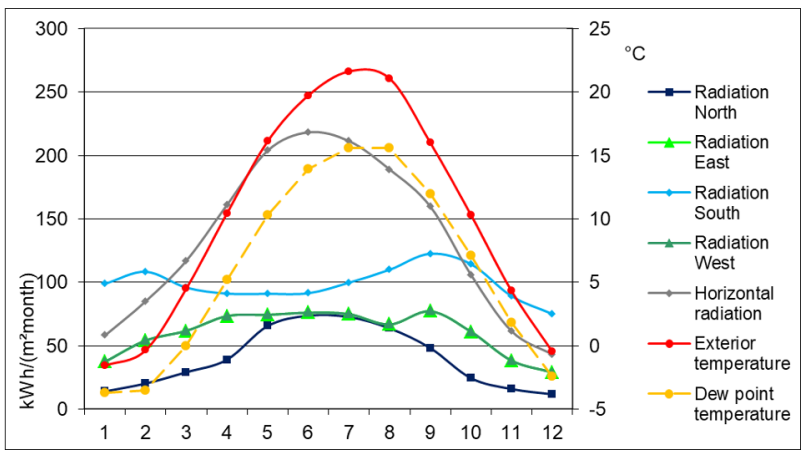

Fig. 3. Climatic data processed for Câmpina 
Regarding the energy model (PHPP), the thermal and electrical energy for heating, cooling, humidification/ dehumidification, domestic hot water, lighting, ventilation and auxiliary energy are considered separately inside the assessment boundaries. The interactions between the different energy services (such as heating, cooling, lighting) are taken into account by the calculation of heat gains and recoverable system losses which can have a positive or negative impact on the energy performance of the building. The Energy Performance (EP) is expressed as the building global primary energy demand divided by the conditioned area [7]. The global primary energy refers to all the EPB energy services and for checking the compliance with EnerPHit standard the electricity for appliances is also included. EP can either include only non-renewable energy $\left(\mathrm{EP}_{\text {nren }}\right)$, or include both non-renewable energy and renewable energy $\left(\mathrm{EP}_{\text {tot }}\right)$ :

$$
\mathrm{EP}_{\text {tot }}=\mathrm{EP}_{\text {nren }}+\mathrm{EP}_{\text {ren }}
$$

The Renewable Energy Ratio (RER) is the ratio of renewable primary energy to the total primary energy:

$$
\mathrm{RER}=\mathrm{EP}_{\text {ren }} / \mathrm{EP}_{\text {tot }}
$$

The renewable, the non-renewable and the total primary energy factors and the $\mathrm{CO}_{2}$ emissions factors are defined at national level [3].

\subsubsection{Global cost model}

For the evaluation of economic feasibility/ efficiency of the renovation measures, the Global Cost (GC) model is used, calculated as the net present value of all costs (referred to the starting year), determined according to [8]. The Global Cost is linked to the calculation period (usually 20 or 30 years) and includes investment costs for refurbishment; replacement costs; running annual costs.

The calculation of the global cost $\mathrm{C}_{\mathrm{g}}(\mathrm{t})$ referred to the starting year $\mathrm{t}_{0}$ is performed by considering the initial investment $C_{I}$ for individual package of measures $j$, the annual costs $C_{a}$ and the discount factor $R_{\text {disc }}(i)$ for every year $\mathrm{i}$ (referred to the starting year), the final value $\mathrm{Val}_{\mathrm{F}}$. The global cost is directly linked to the duration of the calculation period $\mathrm{t}$ :

$$
\mathrm{C}_{g}(\mathrm{t})=\mathrm{C}_{\mathrm{I}}+\sum_{\mathrm{j}}\left[\sum_{\mathrm{i}=1}^{\mathrm{t}}\left(\mathrm{C}_{a, \mathrm{i}}(\mathrm{j}) \cdot \mathrm{R}_{\text {disc }}(\mathrm{i})\right)-\mathrm{Val}_{F, \mathrm{t}}(\mathrm{j})\right]
$$

The residual (final) value of a building variant (with applied package of measures) is determined by straightline depreciation of the initial investment until the end of the calculation period and referred to beginning of the calculation period. Replacement costs and residual values are necessary to correctly compare measures with different lifespan.

The discount factor $R_{\text {disc }}(i)$, for every year $i$, is a multiplicative number used to convert a cash flow occurring at a given point in time to its equivalent value at the starting point. The discount factor is derived from the discount rate $r$ and is calculated as in Eq. (4) where $i$ is the number of years from the starting period.

$$
R_{\text {disc }}(i)=\left(\frac{1}{1+\frac{\mathrm{r}}{100}}\right)^{i}
$$

The energy renovation costs are evaluated by a full cost approach, including design, purchase of building elements, connection to suppliers, installation and commissioning process. These costs are those presented to the customer taking into account also the cost of ancillary works, e.g. scaffolding of a new chimney, professional fees and taxes. However, since the focus of the exercise is the comparison of measures/ packages/ variants (and not the assessment of total costs for the investor and building user), the cost related to building elements not having an influence on the energy performance of the building, i.e. all costs related to the refurbishment of the building without energy savings impact (e.g. repairs at building components level, replacement of roof covering) may be omitted from the calculation:

The calculation period was considered 20 years. A greater value could be considered, but the chosen period could be seen as conservative from the point of view of costs feasibility. If the results for 20 years are favourable, then the economic efficiency would be better for a greater period.

\subsection{Proposals for energy renovation}

The building is considered as residential use building divided into two separate modules and has been modelled in two variants of renovation depending on the intention to use the attic area/volume or not, as follows:

Model 1: the conditioned space includes the ground floor and the first floor, while the basement and attic are unheated, technical spaces. (Figure 4),

Model 2: the conditioned space includes the ground floor and the first floor and the heated attic while the basement remains unheated, technical space. (Figure 5).

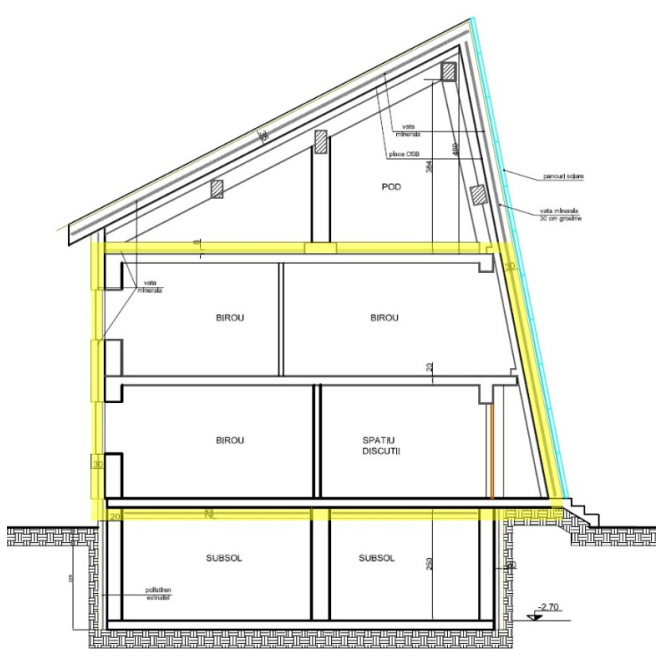

Fig. 4. Model 1: Definition of thermal envelope 


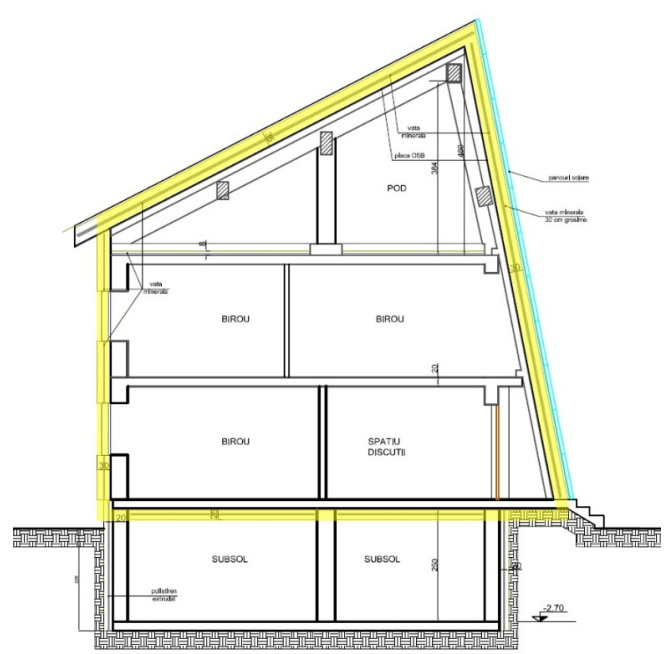

Fig. 5. Model 2: Definition of thermal envelope

From the analysis point of view, the current situation is represented by the building with initial characteristics and current performances, i.e. solar technologies not functioning, with space heating and DHW supplied by direct electric heaters. No mechanical ventilation or cooling exists (natural ventilation by opening windows and air infiltration. The proposed renovation measures were limited to the available electricity supply (no gas or district heating supply is available for the building).

For the energy renovation of the building the application of following measures was considered:

- Thermal insulation of external walls (ETICS) to the ground floor and $1^{\text {st }}$ floor for Model 1 and in addition to attic for Model 2 with basaltic mineral wool slabs; for durability, the protective and finishing coat is made in successive layers with a total thickness of 10 .. $15 \mathrm{~mm}$ and is armed with a dense fibre fabric, permeable to water vapor, but waterproof to precipitation water.

- Thermal insulation of the inclined wall (base panes) with basaltic mineral wool mounted on a $22 \mathrm{~mm}$ OSB support (for the $1^{\text {st }}$ floor inclined wall in Model 1 and for the whole surface, including the attic, for Model 2).
- The roof insulation of the attic to the north with basaltic mineral wool, mounted on a $22 \mathrm{~mm}$ OSB support (only for Model 2).

- Thermal insulation of the floor slab to the attic with mineral wool (only for Model 1).

- Thermal insulation (on the lower side) of the floor slab to the unheated basement, with mineral wool.

- Thermal insulation of the exterior wall of the basement with extruded polystyrene.

- Replacement of the existing windows and doors with thermal insulating windows / doors with and triple glazing and thermal breaking.

- Ensuring airtightness of the outer walls and the floor above the floor by the application of an airtight interior plaster with a minimum thickness of $15 \mathrm{~mm}$.

- Air seals for the installation of ventilation ducts and cold / hot water and sewerage pipes with sealing foil and sealing strips.

- Ensure continuity of airtight layer when joining between exterior walls and window frame by applying sealing membranes/tapes.

The proposed solutions are aimed at improving the energy performance of the building at the nZEB level and focusing on the green building concept by making the most of the organic-natural insulation materials. Different thicknesses of the insulation layers and building systems have been envisaged based on the specific variant and selected of measures. A total of five packages of measures have been defined, leading to 6 simulated situations (variants), as follows:

1 - Existing building: only measures to bring the building functional (e.g. repairs)

2 - Moderate retrofit (minimum requirements) - classic retrofit measures to comply with legal requirements)

3 - Intermediate retrofit (better performances)

4 - EnerPHit (renovation to comply with the EnerPHit standard)

5 - EnerPHit + ST (solar thermal systems for space heating added to variant 4$)$

6 - EnerPHit + ST + PV (PV system added to variant 5).

The five renovation variants (variants 2 to 6) are presented in table 4 for the 2 building models defined.

Table 4. Description of renovation packages of measures

\begin{tabular}{|l|c|c|c|c|c|c|c|c|c|c|c|}
\hline \multirow{2}{*}{ Building component / system } & \multirow{2}{*}{ Unit } & \multicolumn{3}{c|}{ Renovation variants Model 1 } & \multicolumn{5}{c|}{ Renovation variants Model 2 } \\
\cline { 4 - 11 } & & $\mathbf{2}$ & $\mathbf{3}$ & $\mathbf{4}$ & $\mathbf{5}$ & $\mathbf{6}$ & $\mathbf{2}$ & $\mathbf{3}$ & $\mathbf{4}$ & $\mathbf{5}$ & $\mathbf{6}$ \\
\hline Insulation thickness External walls & $\mathrm{mm}$ & 100 & 150 & 300 & 300 & 300 & 100 & 150 & 300 & 300 & 300 \\
\hline Insulation thickness Inclined wall (attic) & $\mathrm{mm}$ & - & - & - & - & - & 200 & 300 & 400 & 400 & 400 \\
\hline Insulation thickness Inclined wall (main zone) & $\mathrm{mm}$ & 200 & 300 & 400 & 400 & 400 & - & - & - & - & - \\
\hline Insulation thickness Slab under attic & $\mathrm{mm}$ & 200 & 300 & 400 & 400 & 400 & - & - & - & - & - \\
\hline Insulation thickness Slab over basement & $\mathrm{mm}$ & 80 & 150 & 200 & 200 & 200 & 80 & 150 & 200 & 200 & 200 \\
\hline U-value windows (average, installed) & $\mathrm{W} / \mathrm{m}^{2} \mathrm{~K}$ & 1.61 & 1.23 & 0.77 & 0.77 & 0.77 & 1.61 & 1.23 & 0.77 & 0.77 & 0.77 \\
\hline g-value - glazing (average) & - & 0.65 & 0.55 & 0.5 & 0.5 & 0.5 & 0.65 & 0.55 & 0.5 & 0.5 & 0.5 \\
\hline Ventilation system & $\mathrm{type}$ & $\mathrm{Nat}$ & $\mathrm{Nat}$ & $\mathrm{HR}$ & $\mathrm{HR}$ & $\mathrm{HR}$ & $\mathrm{Nat}$ & $\mathrm{Nat}$ & $\mathrm{HR}$ & $\mathrm{HR}$ & $\mathrm{HR}$ \\
\hline Effective HR efficiency & $\%$ & - & - & 71.3 & 83.7 & 83.7 & - & - & 71.3 & 83.7 & 83.7 \\
\hline Area of installed solar collectors & $\mathrm{m}^{2}$ & - & - & - & 8 & 8 & - & - & - & 8 & 8 \\
\hline Area of installed PV panels & $\mathrm{m}^{2}$ & - & - & - & - & 53 & - & - & - & - & 53 \\
\hline
\end{tabular}


For renovation package 2 the windows will be installed within the brick layer with max. $2 \mathrm{~cm}$ lintel insulation covering the frame, while for the intermediate and EnerPHit renovation packages (3 to 6) all windows are to be installed in line with the external insulating layer, by means of special insulated frames/fixings.

In addition to global energy performance, the building envelope as a whole and the building components must also meet the specific performance criteria for thermal comfort and for the transfer of heat and mass through the closing elements provided by the technical regulations in force.

\section{RESULTS AND DISCUSSION}

\subsection{Results for Model 1 (attic outside building envelope)}

Model 1 represent the renovation of the building in its current functional use, i.e. with the conditioned space including the ground floor and the first floor, while the unheated basement and attic are kept in the unheated area. The total net floor area of the building is $172 \mathrm{~m}^{2}$ (which is the reference floor area for the energy performance calculations) and the interior volume is $458 \mathrm{~m}^{3}$. The shape factor of the building (A/V ratio) is $0.69 \mathrm{~m}^{2} / \mathrm{m}^{3}$ (calculated with external dimensions).

The heating and cooling demand of the existing building is $401 \mathrm{kWh} / \mathrm{m}^{2} \mathrm{a}$ (with an acceptable frequency of overheating $\left(>25^{\circ} \mathrm{C}\right)$ of $\left.5.2 \%\right)$, which can be reduced to $112 \mathrm{kWh} / \mathrm{m}^{2} \mathrm{a}$ for the classic retrofit (2), to $54 \mathrm{kWh} / \mathrm{m}^{2} \mathrm{a}$ for the more ambitious renovation (3) and to $26 \mathrm{kWh} / \mathrm{m}^{2} \mathrm{a}$ for EnerPHit, as illustrated in Figure 6 .

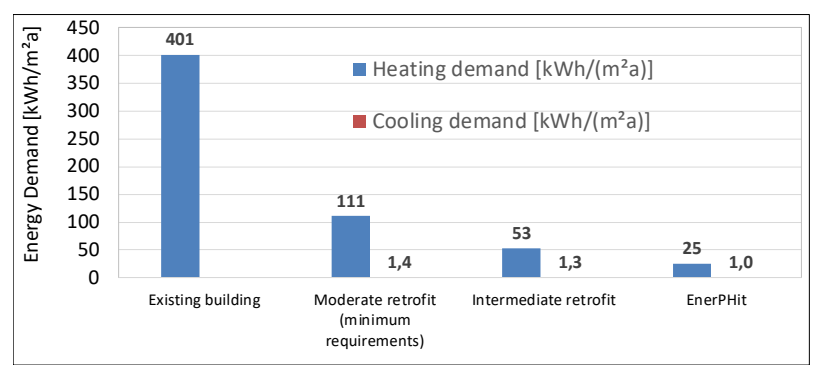

Fig. 6. Specific yearly heating and cooling demand

A comparison between the three levels of building renovation (2, 3 and 4-6) in terms of the energy balance for space heating is presented in Figure 7 detailing the heat losses per components and heat gains. While the heat losses through building envelope components are significantly reduced by applying thermal insulation on opaque elements and installing high performance windows, the weight of solar gains (although reduced by the triple glazing) and ventilation heat load are increasing in the overall reduced energy balance heating (different scales for the 4 variants analysed). In particular, the impact of heat recovery from the extracted air in variants 3 and 4 is obvious compared with the first two ones.

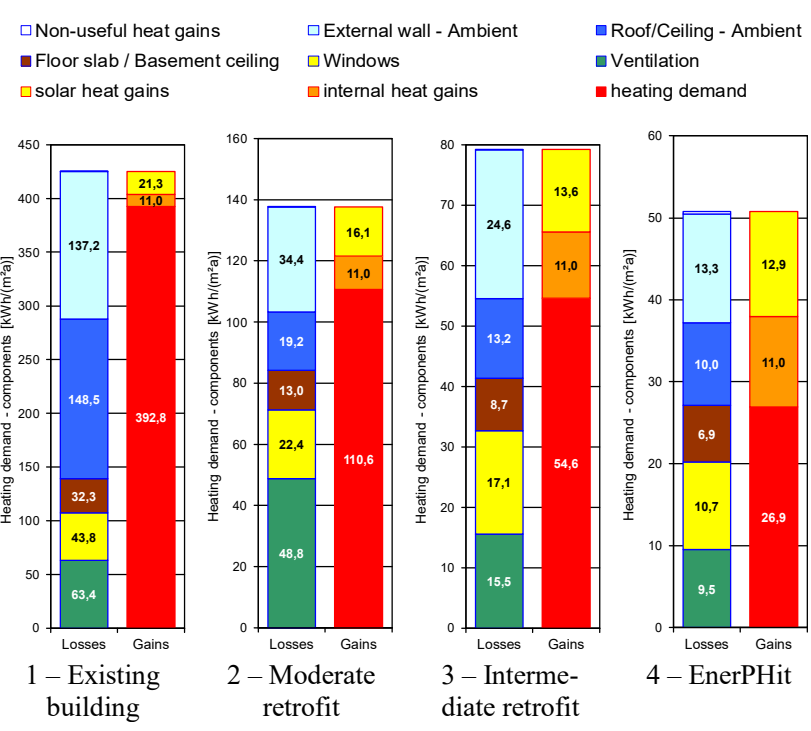

Fig. 7. Energy balance heating (annual method) $\left[\mathrm{kWh} / \mathrm{m}^{2} \mathrm{a}\right]$

For the classic retrofit (2) the ventilation is natural, while for the other renovation variants balanced flow mechanical ventilation systems with heat recovery (nominal efficiency $75 \%$, specific electricity $0.45 \mathrm{Wh} / \mathrm{m}^{3}$ for variant 3 and nominal efficiency $88 \%$, specific electricity $0.39 \mathrm{Wh} / \mathrm{m}^{3}$ for variants 4 to 6) are installed. The 2 ventilation units will be installed in the unheated basement, each plant will serve half the building. The air distribution ducts will be mounted partially in the basement area and will be made of spiral or plastic spherical air ducts with fuel class "0".

The preheated supply air is introduced in the main occupied spaces (living rooms, bedrooms, offices) while the indoor air is extracted from polluted rooms (bathroom, kitchen, WC). The transfer areas (e.g. hall, stairs) are ventilated through the transfer grilles mounted at the bottom of the interior doors. All air ducts will be thermally insulated with minimum $10 \mathrm{~cm}$ vapour resistant insulation for air ducts installed in the basement, while the supply and extract air ducts installed inside building envelope are not insulated.

The space heating and cooling will be ensured by reversible split units (one each floor and apartment).

Regarding the lighting system, the average lighting efficiency was considered to $9.4 \mathrm{~lm} / \mathrm{W}$ (incandescent bulbs) for existing situation and for classic retrofit, $35 \mathrm{~lm} / \mathrm{W}$ (mix of halogen bulbs and compact fluorescent lamps) for the intermediate retrofit and $65 \mathrm{~lm} / \mathrm{W}$ (LED Retro warm white) for the EnerPHit variants.

The domestic hot water (DHW) is prepared by an electric boiler (200 litres) for each apartment. For renovation variants 5 and 6 a solar thermal system with $4 \mathrm{~m}^{2}$ ( 2 collectors) for each apartment will be installed on the inclined wall South oriented, which supply part of the DHW demand throughout the year. The thermal agent will be antifreeze type (e.g. ethylene glycol) to prevent frost during winter.

For the renovation variant 6 , a photovoltaic system is envisaged as on-grid system, consisting of: monocrystalline PV panels mounted on the southern inclined wall (allowing optimal operation), inverter, 
panel mounting system, and (optional) batteries for storing power products, load regulators, protective electrical panel, power cable and battery connections.

The surface available for mounting the panels is about $125 \mathrm{~m}^{2}$, which permits the installation of both solar thermal collectors and photovoltaic panels. A number of $32 \mathrm{PV}$ panels are to be installed for the building (supplying electricity to both apartments), with a total nominal power of $7.5 \mathrm{kWp}$ and a total area of $53 \mathrm{~m}^{2}$; the total energy produced by the photovoltaic system is $7.0 \mathrm{MWh} / \mathrm{a}$, which is intended to cover all building EP uses and the energy demand of appliances.

The non-renewable (NR) final energy demand, total and split by services, is presented in Figure 8 for the current state and all five renovation variants. Since electricity is the only energy used for the building it makes sense to add final energies for different services.

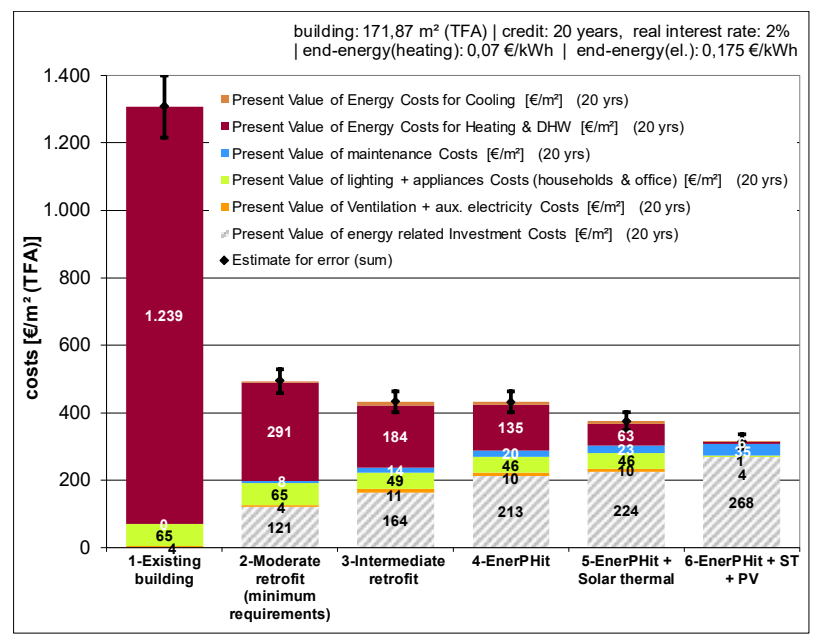

Fig. 8. Final NR energy demand (total and per uses) - Model 1

The investment costs for the energy renovation packages vary from 34.860 EUR for the classic renovation variant (2) to 47.200 EUR for the intermediate variant (3), 61.200 EUR for the EnerPHit variant (4), 64.400 EUR for the EnerPHit variant with solar thermal system up to 77.200 EUR for the maximal (6) variant (PV system added). The specific costs (reference to the total net floor area) per variant and building component / system is presented in Figure 9.

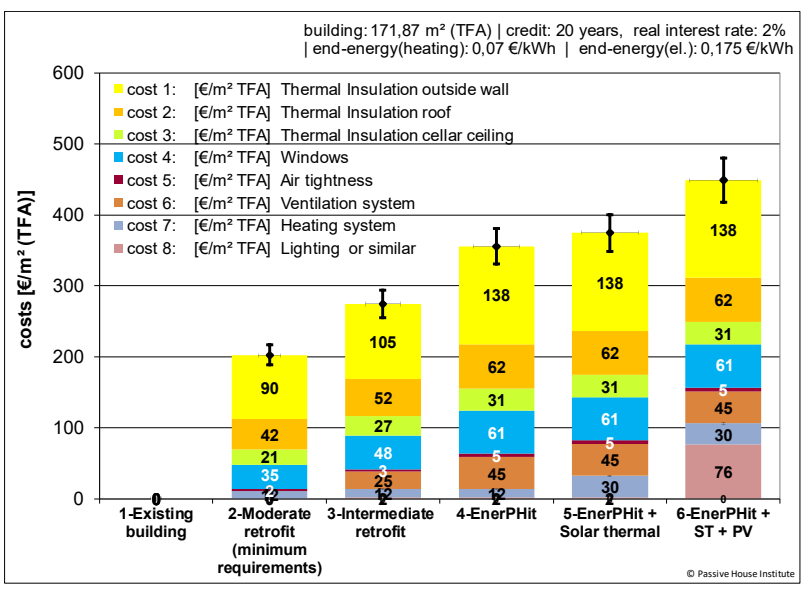

Fig. 9. Investment costs for renovation (Model 2)
The Global Cost calculated as net present value of all costs (investment costs for renovation; replacement and maintenance costs and operation annual costs) for a period of 20 years and referred to the starting year is presented in Figure 10 for the current situation and for the 5 renovation variants taken into consideration. The investment costs are obtained through a loan taken for the same period of 20 years with a real interest rate of $1.98 \%$ (nominal interest rate of $3 \%$, inflation $1 \%$ ).

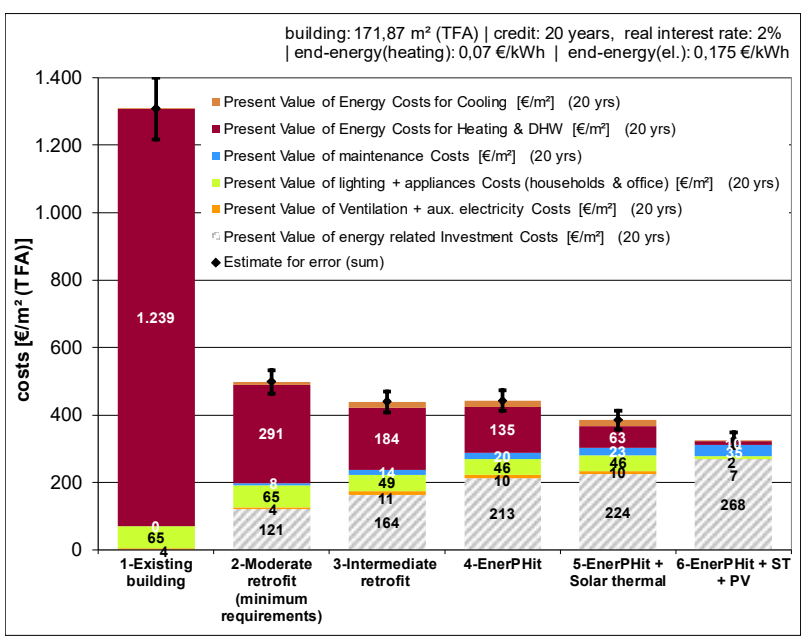

Fig. 10. Comparison of global costs over 20 years period (Model 1)

The cost of electrical energy was based on the current price of 0.125 EUR per $\mathrm{kWh}$, with an assumed average future price for electrical energy (calculation period) of $0.175 € / \mathrm{kWh}$.

\subsection{Results for Model 2 (attic included in the building envelope)}

Model 2 represent the renovation of the building with the increase of existing useful area/volume by including the attic together with the ground floor and the first floor in the conditioned space, while the basement is kept in the unheated area. The total net floor area of the building (reference floor area for energy performance calculations) is $228 \mathrm{~m}^{2}$ and the interior volume is $680 \mathrm{~m}^{3}$. The shape factor of the building (A/V ratio) is $0.59 \mathrm{~m}^{2} / \mathrm{m}^{3}$ (calculated with external dimensions).

The heating and cooling demand of the existing building is $340 \mathrm{kWh} / \mathrm{m}^{2}$ a (with an acceptable frequency of overheating $\left(>25^{\circ} \mathrm{C}\right)$ of $4.7 \%$ ), which is reduced to $111 \mathrm{kWh} / \mathrm{m}^{2} \mathrm{a}$ for the classic retrofit (2), to $53 \mathrm{kWh} / \mathrm{m}^{2} \mathrm{a}$ for the more ambitious renovation (3) and to $26 \mathrm{kWh} / \mathrm{m}^{2} \mathrm{a}$ for EnerPHit.

The same assumptions are made for building services and equipment performances, as it was mentioned above in paragraph 3.1.

The non-renewable (NR) final energy demand, total and split by services, is presented in Figure 11 for the current state and all five renovation variants. The total final energy of the building can be reduced from 379 $\mathrm{kWh} / \mathrm{m}^{2} \mathrm{a}$ ( 1 - existing building) to $114 \mathrm{kWh} / \mathrm{m}^{2} \mathrm{a}$ for the classic retrofit (2), to $73 \mathrm{kWh} / \mathrm{m}^{2} \mathrm{a}$ for the more 
ambitious renovation (3) and to $54.1 \mathrm{kWh} / \mathrm{m}^{2} \mathrm{a}$ for EnerPHit, while with the energy supply from RES, it could go to $33.3 \mathrm{kWh} / \mathrm{m}^{2}$ a with solar thermal system and to $11.4 \mathrm{kWh} / \mathrm{m}^{2} \mathrm{a}$ if PV system is added.

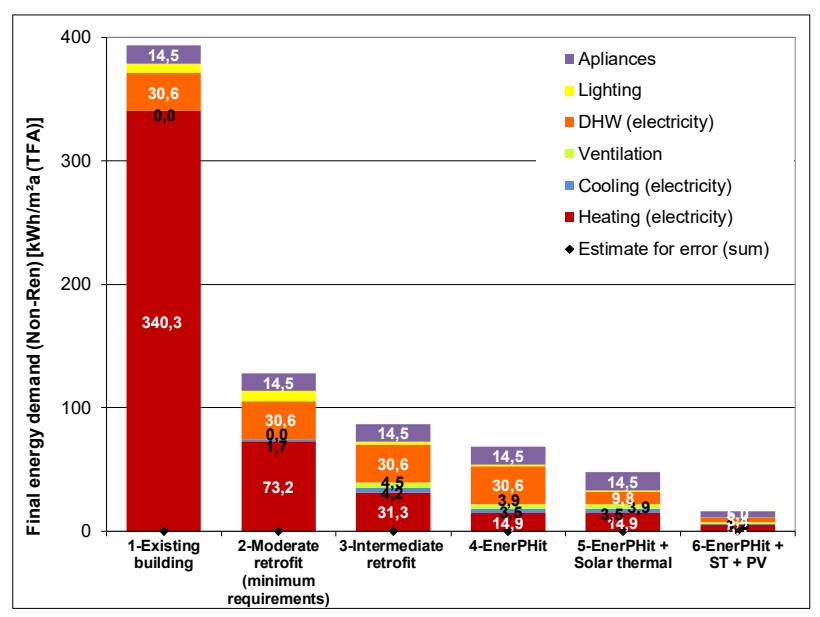

Fig. 11. Final NR energy demand (total + per uses) - Model 2

The final energy demand per uses, the primary energy for EPB uses (renewable, non-renewable and total) and the other performance indicators relevant to analyse the compliance with minimum requirements for renovation and nZEB standard are presented in table 5.

The investment costs for the energy renovation packages starts from 37.725 EUR for the classic renovation variant (2) to 51.800 EUR for the intermediate variant (3), 67.450 EUR for the EnerPHit variant (4), 70.650 EUR for the EnerPHit variant with solar thermal system up to 83.450 EUR for the maximal (6) variant (PV system added). The specific costs (reference to the total net floor area) per variant and building component / system are presented in Figure 12.

The total investment costs are bigger than the ones needed for Model 1 (to cover the larger conditioned area), but the specific costs are reduced, taking into account the bigger total net floor area (TFA).

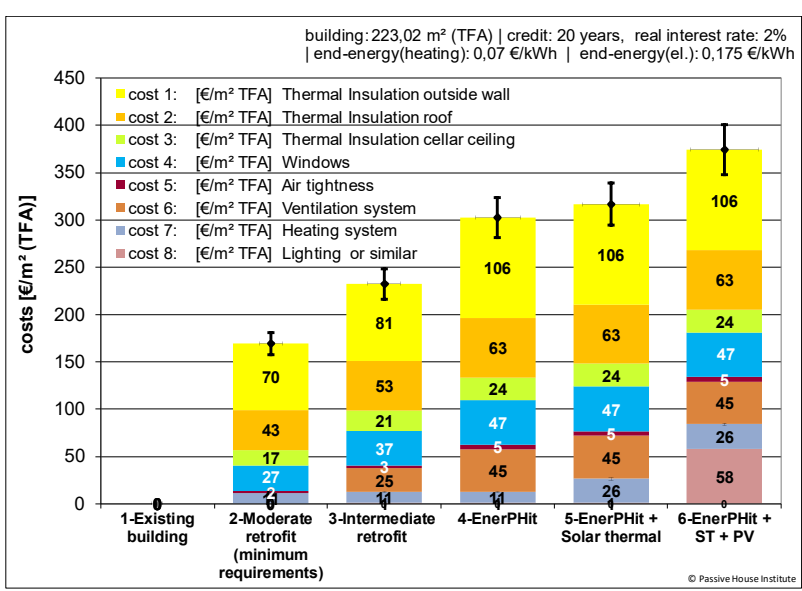

Fig. 12. Investment costs for renovation (Model 2)

The Global Cost for Model 2 calculated for a period of 20 years and referred to the starting year is presented in Figure 13 for all variants. The loan conditions and the price of energy are the same as in the Model 1 case.

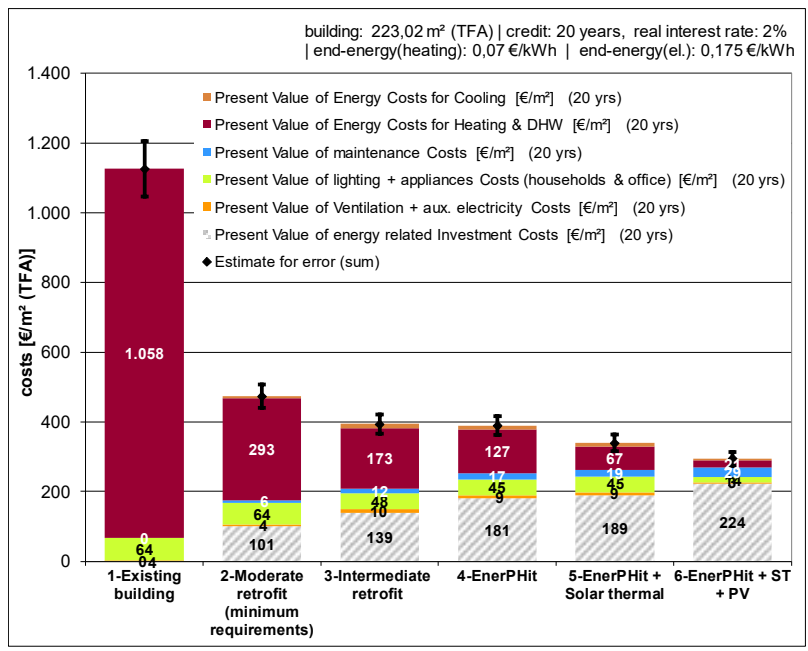

Fig. 13. Comparison of global costs over 20 years period

Table 5. Performance indicators relevant for nZEB (NR - non-renewable)

\begin{tabular}{|c|c|c|c|c|c|c|c|c|c|c|c|c|c|}
\hline \multirow{2}{*}{ Results } & \multirow{2}{*}{ Unit } & \multicolumn{6}{|c|}{ Renovation variants Model 1} & \multicolumn{6}{|c|}{ Renovation variants Model 2} \\
\hline & & 1 & 2 & 3 & 4 & 5 & 6 & 1 & 2 & 3 & 4 & 5 & 6 \\
\hline Final energy demand (NR) - Heating & $\mathrm{kWh} / \mathrm{m}^{2} \mathrm{a}$ & 401 & 69.7 & 32.2 & 15.1 & 15.1 & 1.9 & 340 & 73.2 & 31.3 & 14.9 & 14.9 & 5.1 \\
\hline Final energy demand (NR) - Cooling & $\mathrm{kWh} / \mathrm{m}^{2} \mathrm{a}$ & & 1.4 & 3.6 & 3.0 & 3.0 & 0.4 & - & 1.7 & 4.2 & 3.5 & 3.5 & 1.2 \\
\hline Final energy demand (NR) - Ventilation & $\mathrm{kWh} / \mathrm{m}^{2} \mathrm{a}$ & - & - & 4.3 & 3.8 & 3.8 & 0.5 & - & - & 4.5 & 3.9 & 3.9 & 1.3 \\
\hline Final energy demand (NR) - DHW & $\mathrm{kWh} / \mathrm{m}^{2} \mathrm{a}$ & 33.6 & 33.6 & 33.6 & 33.6 & 8.6 & 1.1 & 30.6 & 30.6 & 30.6 & 30.6 & 9.8 & 3.4 \\
\hline Final energy demand (NR) - Lighting & $\mathrm{kWh} / \mathrm{m}^{2} \mathrm{a}$ & 7.8 & 7.8 & 2.1 & 1.1 & 1.1 & 0.1 & 8.0 & 8.0 & 2.1 & 1.2 & 1.2 & 0.4 \\
\hline Final energy demand (NR) - Appliances & $\mathrm{kWh} / \mathrm{m}^{2} \mathrm{a}$ & 15.0 & 15.0 & 15.0 & 15.0 & 15.0 & 1.9 & 14.5 & 14.5 & 14.5 & 14.5 & 14.5 & 5.0 \\
\hline PE demand EPB - TOTAL & $\mathrm{kWh} / \mathrm{m}^{2} \mathrm{a}$ & 1159 & 295 & 199 & 148 & 108 & 108 & 993 & 297 & 190 & 142 & 108 & 108 \\
\hline PE demand - Heating Non-renewable & $\mathrm{kWh} / \mathrm{m}^{2} \mathrm{a}$ & 1050 & 183 & 84.3 & 39.6 & 39.6 & 5.0 & 892 & 192 & 81.9 & 39.1 & 39.1 & 13.5 \\
\hline PE demand EPB - Renewable & $\mathrm{kWh} / \mathrm{m}^{2} \mathrm{a}$ & - & - & - & - & 25.0 & 97.3 & - & - & - & - & 20.8 & 78.0 \\
\hline PE demand EPB - Non-renewable & $\mathrm{kWh} / \mathrm{m}^{2} \mathrm{a}$ & 1159 & 295 & 199 & 148 & 82.7 & 10.5 & 993 & 297 & 190 & 142 & 87.2 & 30.0 \\
\hline Total CO2 Emissions & $\mathrm{kgCO}_{2} / \mathrm{m}^{2} \mathrm{a}$ & 132 & 33.7 & 22.7 & 16.9 & 9.4 & 1.2 & 113 & 33.9 & 21.7 & 16.2 & 10.0 & 3.4 \\
\hline$\%$ Contribution Renewables & $\%$ of $\mathrm{PE}$ & - & - & - & - & 21.1 & 84.3 & - & - & - & - & 17.9 & 68.4 \\
\hline
\end{tabular}




\subsection{Discussions}

For variant 4 - EnerPHit, the heating demand is $25 \mathrm{kWh} / \mathrm{m}^{2} \mathrm{a}$ for Model 1 and $24.7 \mathrm{kWh} / \mathrm{m}^{2} \mathrm{a}$ for Model 2, while the total non-renewable primary energy (all uses, including appliances) is $107.7 \mathrm{kWh} / \mathrm{m}^{2} \mathrm{a}$ for Model 1 and $108.0 \mathrm{kWh} / \mathrm{m}^{2}$ a for Model 2. Moreover, at component level all characteristics comply with the limit values imposed by the EnerPHit standard. Thus, the renovated building complies with the EnerPHit standard both by energy demand method and by component method, as Passive House Classic. With 40 PV panels installed for Model 1 and with 44 PV panels installed for Model 2 respectively, the building would comply with the Passive House Plus (Retrofit).

From the national requirements point of view, the classic renovation variant (2) complies with minimum thermal requirements (performances for building envelope), but does not comply with the criteria for nonrenewable primary energy for heating $\left(<153 \mathrm{kWh} / \mathrm{m}^{2} \mathrm{a}\right)$. The requirements could easily be met if either a mechanical ventilation with heat recovery system is installed and/or by changing the energy source with a lower PE factor. The minimum EP requirements for deep renovation are achieved for variants 3 to 6 , while the nZEB levels for houses are achieved for variants 5 and 6 . The requirements set for new built office buildings could not be met even by the EnerPHit + ST + PV variant (6).

Compared with the existing building, all renovation variants are cost-effective on long term (20 years). The global costs of Intermediate renovation (3) and EnerPHit (4) variants are almost identical, while the energy performance of the latter is $23 \%$ better than the former one. The optimum variant seems to be variant 6 (nZEB).

The results are valid for the assumption that only the costs of energy renovation measures are included and the high cost effectiveness of the renovation packages is explained both by the poor performance of the existing building and the use of electricity for all services (with high PE factor and unitary energy price). However, even if the repair costs (retrofit at roof, basement and façade level, windows and interior finishing improvement), which have no energy impact, are taken into account (361 EUR/m² TFA for Model 1 and $310 \mathrm{EUR} / \mathrm{m}^{2} \mathrm{TFA}$ for Model 2), the renovation measures will still be cost effective (in terms of global costs for 20 years period), while the maximal variant (6) remains the optimal one in both building simulation models.

\section{CONCLUSIONS}

In this paper a case study on the model renovation of an existing duplex residential building at nZEB levels through Passive House Expertise, is presented. The original building is an experimental building from the 80's using solar technologies for DHW and (active and passive) space heating.

Starting from the existing state of the building which is brought to a functional status to enable occupation, but having a poor thermal and energy performance, several renovation packages are proposed and analysed from both energy performance and global costs perspectives: classic renovation (targeting compliance with mandatory minimum requirements and low budget of the owner), EnerPHit standard (with an intermediate renovation variant) and two variants considering solar thermal and photovoltaic systems added to the Passive House retrofitted building.

The analysis was performed using the PHPP tool developed by the Passive House Institute and additional calculations to respond to national EP calculations. The results show a reduction in the total annual heating demand to 28\% (Model 1) and 32\% (Model 2) with the classical retrofit (to minimum requirements for deep energy renovation) and to 6\% (Model 1) and 7\% (Model 2) with complying to EnerPHit standard. The primary energy non-renewable is reduced with $75 \%$ (Model 1) and $70 \%$ (Model 2) by renovating at the building code, with the classical retrofit, with $87 \%$ (Model 1) and $86 \%$ (Model 2) by renovating at Passive House standard, while the maximum renovation package lead to a $98 \%$ reduction (Model 1) and 97\% reduction (Model 2) of the non-renewable primary energy use.

It was shown that Passive House (renovation) and nZEB levels established for new built dwellings can be achieved in cost effectiveness conditions (20 years). In addition, by using organic-natural insulation materials (e.g mineral wool, wooden frames), the LC carbon footprint of the building can be reduced.

\section{References}

1. Directive 2010/31/EU of the European Parliament and of the Council, Energy performance of buildings (recast). Official Journal of the European Union L153/13-35 (2010)

2. Law 372/2005 regarding Energy Performance of Buildings - transposing the provisions of EPBD (modified and republished in 2016)

3. MC 001-2006, Methodology for Calculation of Energy Performance of Buildings, Ministry of Regional Development and Tourism, Bucharest, Romania (last modified in 2017)

4. C 107-2010 - Normative regarding thermo-technic calculation of construction elements of buildings, Ministry of Regional Development and Tourism, Bucharest, Romania (last modified in 2016)

5. Passipedia, The Passive House - definition, https://passipedia.org/basics/the passive house definition (last accessed January 2019)

6. PHPP 2015 - Passive House Planning Package 2015, Passive House Institute, Darmstadt (2015)

7. EN ISO 52000-1:2017, Energy performance of buildings - Overarching EPB assessment - Part 1: General framework and procedures (2017)

8. EN 15459-1:2017 Energy performance of buildings - Economic evaluation procedure for energy systems in buildings - Part 1: Calculation procedures, Module M1-14 (2017) 